\title{
Experimental and Theoretical Infrared Study of Homogalacturonans in the Psidium Myrtoides - Nothotrioza Myrtoidis System
}

\author{
Renê G. S. Carneiro, Rosy M. S. Isaias, Bárbara D. L. Ferreira, Breno R. L. Galvão, \\ Cláudio L. Donnici \& Rita C. O. Sebastião
}

\section{Introduction}

Structural and functional properties of plant cells rely on the composition of cell walls, which may be altered by the influence of galling herbivores ${ }^{1,2}$. The alteration of chemical compounds in plant cell walls may be detected by different techniques as the absorption of infrared light and nuclear magnetic resonance (NMR) $)^{3,4}$. The use of infrared absorption spectra allows the identification of molecular structures by the fingerprint of chemical bonds and functional groups, and by chemometric methods analyzing the region of 1000$500 \mathrm{~cm}^{-15,6}$. The fingerprints of chemical compounds may be successfully assessed in complex mixtures, which is the case of plant cell walls?

Plant epidermis mediates the interactions between plant organs and the surrounding environment by lining on both leaf surfaces, and on the inner and outer surface of galls ${ }^{8}$. In the Psidium myrtoides (Myrtaceae) - Nothotrioza myrtoidis (Psylloidea) system, the leaf epidermis undergoes distinct degrees of alterations during gall formation, as evidenced by anatomical, cytological and immunocytochemical analyses $^{9,10}$. The set of structural alterations in the galls of $N$. myrtoidis indicate that the inner epidermis is functionally altered11. Even though the inner and outer gall surfaces have the same ontogenetic origin ${ }^{11,12}$, their structure is distinct and so is the molecular composition of their cell walls. Based on this premise, current study proposes the investigation of the surfaces of non-galled leaves of $P$. myrtoides and leaf galls of $N$. myrtoidis using IR-ATR spectroscopy. Furthermore, we analyze the optimized structure of homogalacturonans (HGAs), which are the main pectins in the cell walls ${ }^{11-13}$, with different degrees of methylation/acetylation. The main objective is to check if gall establishment distinctly affects the molecular structure of the epidermal cell walls on both gall surfaces. We expect distinct fingerprint patterns for the gall and leaf epidermises related to the alterations in the structure of HGAs, with greater cell alterations occurring in the inner epidermis when compared to the outer epidermis of the galls. In addition, we evaluate the efficiency of experimental and theoretical chemical analyses in assessing the structure of HGAs, which should allow new insights on the biology of plant cell walls.

\section{Methods}

We have experimentally analyzed fresh nongalled leaves and galls using a zinc-selenium crystal ATR apparatus (Smart orbit ATR, Thermo Fisher Scientific Inc., Madison, USA), coupled with the spectrophotometer FTIR Nicolet 380 (Thermo Fisher Scientific Inc., Madison, USA), and submitted the samples to infrared radiation between $4000-525 \mathrm{~cm}^{-1}$. Series of 32 scannings with the resolution of $2 \mathrm{~cm}$ were performed. Additionally, we theoretically simulated the infrared spectrum of HGAs of several degrees of methylation, with and without acetyl groups. Given the large number of atoms involved, we have started the analysis at the Hartree-Fock level. However, we currently worked on higher level calculations, the DFT level, using the B3LYP functional, and including Grimme's empirical dispersion correction in order to improve the description of intra-molecular interactions ${ }^{13,14}$. Geometry 
optimizations are followed by calculations of the Hessian matrix, in order to extract the vibrational frequencies. All electronic structure calculations were performed using the GAMESS package ${ }^{16}$.

\section{Results and Discussion}

The experimental ATR-IR spectra of the adaxial epidermis of non-galled leaves and the inner epidermis of galls are remarkably different, especially at the 3500$3000 \mathrm{~cm}^{-1}$ and $1750-1600 \mathrm{~cm}^{-1}$ regions. In the spectra of non-galled leaves, three intense bands were found at 3360,1727 and $1642 \mathrm{~cm}^{-1}$, being the second band more intense $(\sim 87 \%, 75 \%$, and $84 \%$ transmittance $=\mathrm{T})$. In the spectra of galls, the band at $3360 \mathrm{~cm}-1$ is more intense than the corresponding band in the non-galled leaves $(\sim$ $57 \% \mathrm{~T})$. The band at $1727 \mathrm{~cm}^{-1}$ is less intense in galls $(\sim$ $89 \% \mathrm{~T})$, and the band at $1642 \mathrm{~cm}^{-1}$ is more intense in galls $(\sim 68 \% \mathrm{~T})$ when compared to the bands of non-galled leaves. Immuncytochemical investigations using specific antibodies for homogalacturonans (HGAs) with different levels of methylation revealed that the adaxial epidermis of non-galled leaves have low methylated HGAs, and the inner epidermis of galls have high methylated HGAs in their cell walls ${ }^{1}$. The strong intensity of $\mathrm{OH}$ bands in the spectra of galls could be attributed to intermolecular Hydrogen bonds ( $\mathrm{H}$ bonds) occurring meanly in the low methylated HGAs. Nevertheless, this hypothesis needs to be proven, and led to the theoretical study.

For the theoretical study, ten molecular structures of HGAs were simulated. Each structure is composed by six monomers of galacturonic acid linked by glucoside bonds. Figure 1 represents the structure of the monomer, with $\mathrm{H}$ as $\mathrm{R}$ and $\mathrm{R} 1$ groups.

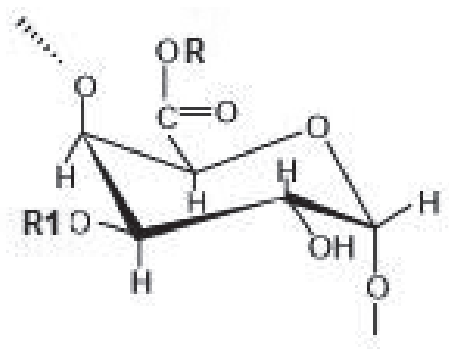

Figure 1. Galacturonic acid monomer.
The structures were divided into two sets: (a) with acetyl group in the R1 position of the fourth and sixth monomers and, (b) without acetyl groups. In both sets, the structures were methyl-esterified in the R position of the monomers: (i) 1,6 ; (ii) $1,2,6$; (iii) $2,3,4,5$; (iv) $3,4,5$ and (v) $1,3,5$.

The $\mathrm{OH}$ band analysis of simulated infrared spectra is presented in Table 1. The $\mathrm{OH}$ bands in acetylated structures always present stronger intensity than in the corresponding non-acetylated. The experimental infrared spectra of galls present similar behavior, i.e. show stronger intensity for $\mathrm{OH}$ band in galls when compared to non-galled leaves. This theoretical result suggests that the structure of HGAs in galls may be composed by acetylated monomers with high degree of methylation. This result adds new information to the experimental detections of high and low methylated HGAs in the plant cell walls using the monoclonal antibodies JIM5 and JIM7, which cannot assess the degree of acetylation of HGAs. Together, the theoretical and experimental studies show that the formation of galls affects both the methylation and acetylation of HGAs, with implications for the functional aspects of plant cell walls.

Table 1. Simulated infrared $\mathrm{OH}$ band with $\mathrm{H}$ bond analysis after geometry optimization.

\begin{tabular}{|c|c|c|c|}
\hline \multirow{2}{*}{$\begin{array}{c}\text { Monomers } \\
\text { methylation and/or } \\
\text { acetylation }\end{array}$} & \multicolumn{2}{|c|}{$\mathrm{OH}$ band } & \multirow{2}{*}{$\begin{array}{c}\text { Intra } \\
\text { MolecularH } \\
\text { bond }\end{array}$} \\
\hline & $\mathrm{cm}^{-1}$ & Intensity & \\
\hline 1,6 methylated & 4263.45 & 53.68417 & $\begin{array}{l}\mathrm{HO}---\mathrm{OH} \\
\mathrm{CO}---\mathrm{OH}\end{array}$ \\
\hline $\begin{array}{c}\text { 1,6 methylated and } \\
4,6 \text { acetylated }\end{array}$ & 4238.58 & 66.93222 & $\begin{array}{l}\mathrm{HO}---\mathrm{OH} \\
\mathrm{CO}---\mathrm{OH}\end{array}$ \\
\hline $1,2,6$ methylated & 4266.84 & 53.63021 & $\begin{array}{l}\mathrm{HO}---\mathrm{OH} \\
\mathrm{CO}---\mathrm{OH}\end{array}$ \\
\hline $\begin{array}{l}1,2,6 \text { methylated } \\
\text { and } 4,6 \text { acetylated }\end{array}$ & 4243.64 & 65.38409 & $\begin{array}{l}\mathrm{HO}---\mathrm{OH} \\
\mathrm{CO}---\mathrm{OH}\end{array}$ \\
\hline $1,3,5$ methylated & 4342.67 & 16.59795 & $\begin{array}{l}\mathrm{HO}---\mathrm{OH} \\
\mathrm{CO}---\mathrm{OH}\end{array}$ \\
\hline $\begin{array}{l}1,3,5 \text { methylated } \\
\text { and } 4,6 \text { acetylated }\end{array}$ & 4306.84 & 28.14144 & $\begin{array}{l}\mathrm{HO}---\mathrm{OH} \\
\mathrm{CO}---\mathrm{OH}\end{array}$ \\
\hline $2,3,4,5$ methylated & 4252.92 & 14.62813 & HO---OH \\
\hline $\begin{array}{l}2,3,4,5 \text { methylated } \\
\text { and } 4,6 \text { acetylated }\end{array}$ & 4247.83 & 15.86863 & HO---OH \\
\hline $3,4,5$ methylated & 4251.10 & 13.90583 & HO---OH \\
\hline $\begin{array}{l}3,4,5 \text { methylated } \\
\text { and } 4,6 \text { acetylated }\end{array}$ & 4256.87 & 15.78891 & HO---OH \\
\hline
\end{tabular}


Given that this study was performed on the isolated molecule (gas phase), the role of intermolecular $\mathrm{H}$ bond is not taken into account. Nevertheless, intramolecular $\mathrm{H}$ bond is an important factor that seems to be crucial on elucidating the experimental results. It should also be emphasized that the wave numbers presented in Table 1 are at the Hartree-Fock level, and thus cannot quantitatively describe the system. Our analysis are of qualitative nature, aiming to rationalize the experimental findings. In the structures with higher degree of methylation and/or acetylation, the $\mathrm{CO}-\mathrm{OH}$ interaction between the monomers does not occur. The spatial aspect of the highly methylated and acetylated structure is linear and does not present helical configuration. Figure 2 shows the optimized structure for the (a) 1,6 methylated and (b) 3,4,5 methylated HGAs.
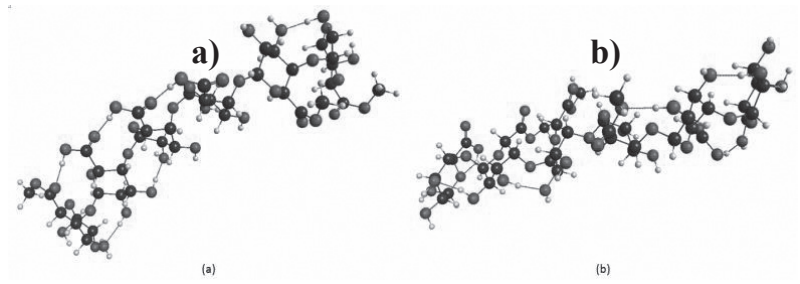

Figure 2. HGAs (a) 1,6 methylated and (b) 3,4,5 methylated.

The analyses of the CO band in the theoretical IR spectra show a general behavior for the structures (a), in which the acetylation determines a reduction in the calculated wavenumber, thus corroborating the experimental results.

\section{Conclusions}

Experimental and theoretical studies on the structure ofHGAs represent new frontiers to help understanding the biology of plant cell walls, as far as the intramolecular and intermolecular forces of polymers are concerned. The simulated infrared absorption of HGAs showed that acetylation affects intramolecular bonds the most, thus being complementary to the immunocytochemical analyses for the degree of HGAs methylation. Further analyses considering the complexity of the cell wall matrix should help elucidating the role of fine structural details of polymers on the functional aspects of the cell walls.

\section{Acknowledgments}

The authors thank FAPEMIG and CNPQ for the financial support.

\section{References}

1. P. Albersheim, A. Darvill, K. Roberts, R. Sederoff, A. Staehelin, Plant cell walls: from chemistry to biology, Garland Science, New York, (2011).

2. D. Burckhardt, Biology, ecology and evolution of gall-inducing psyllids (Hemiptera: Psylloidea). In: A. Raman, C. W. Schaefer, T. M. Withers, Biology, ecology, and evolution of gall-inducing arthropods, Science Publishers, Plymouth, (2005).

3. R. C. O. Sebastião, J. P. Braga, J. Magn. Reson.,177, 146, (2005).

4. R. C. O. Sebastião, C. N. Pacheco, J. P. Braga, D. Piló-Veloso, J. Magn. Reson., 182, 22, (2006).

5. R. G. S. Carneiro, R. M. S. Isaias, Protoplasma, 252, 637, (2014).

6. R. G. S. Carneiro, D. C. Oliveira, R. M. S. Isaias, Pl. Cell. Rep., 33, 2093, (2014).

7. R. G. S. Carneiro, P. Pacheco, R. M. S. Isaias, Plos One, 10, e0129331, (2015).

8. A. A. Christy, S. Kasemsumran, Y. Du, Y. Ozaki, Analytical Sci 20, 935, (2004).

9. R. F. Evert Esau's Plant Anatomy: Meristems, cells, and tissues of the plant body: their structure, function and development, John Wiley \& Sons, Inc., Hoboken, (2006).

10. A. Fahn, Plant anatomy. Pergamon Press, Oxford, (1990).

11. A.T. Formiga, D. C. Oliveira, B. G. Ferreira, T. A. Magalhães, A. C. Castro, G. W. Fernandes, R. M. S. Isaias, Protoplasma, 250, 899, (2013).

12. D. C. Oliveira, T.A. Magalhães, B. G. Ferreira, C. T. Teixeira, A. T. Formiga, G. W. Fernandes, R. M. S. Isaias, Plos One, 9, e94588, (2014a).

13. C. Pasquini, J. Braz. Chem. Soc., 14, 198, (2003).

14. P. J. Stephens, F. J. Devlin, C. F. Chabalowski, M. J. Frisch, J. Phys. Chem., 98, 11623, (1994).

15. S. Grimme, J. Antony, S. Ehrlich, H. Krieg, J. Chem. Phys., 132, 154104, (2010).

16. M. W. Schmidt, K. K. Baldridge, J. A. Boatz, S. T. Elbert, M. S. Gordon, J. H. Jensen, S. Koseki, N. Matsunaga, K. A. Nguyen, S. Su, T. L. Windus, M. Dupuis, J. A. Montgomery, J. Comput. Chem., 14, 1347, (1993).

Renê G. S. Carneiro ${ }^{a}$, Rosy M. S. Isaias ${ }^{a}$, Bárbara D. L. Ferreirab, Breno R. L. Galvãoc, Cláudio L. Donnicib, Rita C. O. Sebastião ${ }^{b^{*}}$

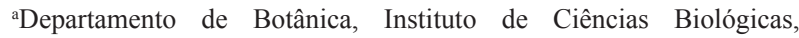
Universidade Federal de Minas Gerais-UFMG. Av. Antônio Carlos, 6627, Belo Horizonte - MG, Brazil

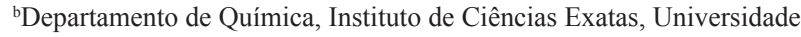
Federal de Minas Gerais-UFMG. Av. Antônio Carlos, 6627, Belo Horizonte - MG, Brazil

${ }^{\mathrm{c} C e n t r o ~ F e d e r a l ~ d e ~ E d u c a c ̧ a ̃ o ~ T e c n o l o ́ g i c a ~ d e ~ M i n a s ~ G e r a i s-~ C E F E T-~}$ MG. Av. Amazonas ,5253, Belo Horizonte - MG, Brazil

*E-mail: ritacos@ufmg.br 